\title{
Biocompatibility of Acetazolamide Pastes in the Subcutaneous Tissue of Rats
}

\author{
Graziela Garrido MORI ${ }^{1}$ \\ Ivaldo Gomes de MORAES ${ }^{2}$ \\ Daniele Clapes NUNES ${ }^{3}$ \\ Lithiene Ribeiro CASTILHO ${ }^{3}$ \\ Wilson Roberto $\mathrm{POI}^{3}$
${ }^{1}$ Department of Integrated Clinic, Adamantina Dental School, Adamantina, SP, Brazil and Department of Integrated Clinic, Araçatuba Dental School, São Paulo State University, Araçatuba, SP, Brazil
${ }^{2}$ Department of Restorative Dentistry, Dental Materials and Endodontics, Bauru Dental School, University of São Paulo, Bauru, SP, Brazil
${ }^{3}$ Department of Integrated Clinic, Araçatuba Dental School, São Paulo State University, Araçatuba, SP, Brazil

\begin{abstract}
This aim of this study was to investigate the biocompatibility of two experimental acetazolamide (AZ)-based pastes in the subcutaneous tissue of rats. Both pastes contained AZ as the main component in similar concentration. The vehicle in experimental paste 1 was saline, while experimental paste 2 was prepared with propylene glycol. Sixty polyethylene tubes were sealed at one end with gutta-percha (GP), which served as a control. Half of the tubes were filled with paste 1 and half with paste 2 . The tubes were implanted in the subcutaneous tissue of 15 rats, being 4 tubes for each animal. The animals were killed 7, 15 and 45 days after surgery and the specimens were processed in laboratory. The histological sections were stained with hematoxylin and eosin and were analyzed by light microscopy. Scores were assigned to level of inflammatory process: 1 - none; 2 - mild; 3 - moderate; 4 - severe. The data were analyzed statistically by the Kruskal-Wallis test ( $\leq \leq 0.05)$. Paste 1 produced an inflammatory process at 7 days. However, the intensity of this inflammation decreased with time and was nearly absent at 45 days. No statistically significant difference $(\mathrm{p}>0.05)$ was observed between the control (GP) and paste 1 . However, paste 2 produced inflammatory response at all study periods and differed significantly $(\mathrm{p}<0.05)$ from the control. In conclusion, in the present study, the experimental AZbased paste 1 was considered as biocompatible as the control matrial (GP), while experimental paste 2 was irritating to rat subcutaneous tissue.
\end{abstract}

Key Words: acetazolamide, biocompatibility, rat.

\section{INTRODUCTION}

Tooth avulsion, characterized by complete displacement of the tooth from the socket, accounts for nearly 0.5 to $16 \%$ of all dental trauma cases (1). Several tissues may be affected or damaged by tooth avulsion, including the periodontal ligament, alveolar bone, gingiva, lips and dental pulp (1). The periodontal ligament is disrupted and has its arrangement disorganized and its viability affected $(1,2)$. The vascular-nerve bundle that supplies the dental pulp is also disrupted, leading to pulp necrosis in most cases (1). Tooth avulsion is thus as a complex traumatic injury with difficult treatment (2). After avulsion, the tooth should be repositioned in the socket in an attempt to reestablish the normality (1). The success of tooth replantation depends on the maintenance of vitality of the cells present on root surface (1). Hence, immediate replantation $(1,3)$ or storage of avulsed teeth in adequate medium to allow survival of these cells until replantation (1) is fundamental.

Studies with different populations reveal an overall lack of knowledge on what should be done in cases of tooth avulsion $(4,5)$. Instead of performing immediate replantation or storing the tooth in adequate medium, people usually let the tooth dry, keeping it wrapped in plastic or paper; or sometimes store the tooth immersed in solutions that do not allow for cell survival. This may lead to ankylosis and root resorption, both undesirable

Correspondence: Profa. Dra. Graziela Garrido Mori, Rua Claudionor Sandoval, 1305, 19023-200 Presidente Prudente, SP, Brasil. Tel: +55-18-39172457. Fax:+55-18-3522-1001. e-mail: grazielagm@hotmail.com 
consequences of tooth replantation $(1,2)$.

In an attempt to prevent or limit the root resorption and promote repair of the area, in case of late replantation, the tooth should be submitted to root surface treatment and endodontic therapy $(1,2)$. Currently, root surface treatment is done with sodium hypochlorite, which removes the root-adhered necrotic remnants without affecting the cementum layer $(2,6)$. Fluoride is applied because it strengthens the tooth structure by the formation of fluorapatite, and also because it is toxic to resorptive cells $(2,6,7)$. Calcium hydroxide is generally accepted as the intracanal medication of choice $(7,8)$ due to its antimicrobial and anti-resorptive characteristics.

Nevertheless, despite these clinical procedures, treatment failure and tooth resorption are not uncommon events. Teeth are ultimately lost after 4 to 6 years on average (9). Thus, the search for new substances that may inhibit or delay the effects of root resorption and promote repair is fundamental.

Mori et al. (2) previously reported that the use of a $10^{-5} \mathrm{M}$ acetazolamide (AZ) solution as an intracanal medication was able to inhibit root resorption in cases of delayed tooth replantation. AZ was more efficient than calcium hydroxide. However, due its liquid presentation, the insertion and retention of $A Z$ inside the root canal are challenging. The development of $\mathrm{AZ}$ pastes would enhance its use as an intracanal medication in teeth susceptible to root resorption. Ideally, the experimental AZ pastes should be biocompatible with the surrounding tissues, since the concentration of AZ in pastes is higher than that in solution (2). Pastes should be further tested in replanted teeth regarding its effectiveness to inhibit root resorption.

This study evaluated the biocompatibility of two experimental AZ-based pastes in rat subcutaneous tissue.

\section{MATERIAL AND METHODS}

Two experimental AZ pastes were tested, oth containing AZ (Deg Produtos Químicos Ltda, CAS 5966-5, São Paulo, SP, Brazil) as the main component in similar concentrations. Saline (Drogaderma, Presidente Prudente, SP, Brazil) and propylene glycol (Drogaderma) were the vehicles in experimental paste 1 (EP1) and experimental paste 2 (EP2).

The study was conducted on 15 male rats (Rattus, norvegicus, albinus, Wistar) weighing 180-200 g. All experimental procedures were approved by the Animal
Ethics Research Committee of Bauru Dental School, University of São Paulo, Brazil (Process 08/2006). The rats were housed in cages cleaned daily and labeled according to the groups and study periods. The animals received and water ad libitum and solid food before and during the study, except for the $12 \mathrm{~h}$ pre-surgery.

The animals were anesthetized with an intramuscular injection of ketamine hydrochloride (Dopalen Sespo Indústria e Comércio Ltda, Jacareí, SP, Brazil) and xylazine hydrochloride (Anasedan Agribrands do Brasil Ltda., Jacareí, SP, Brazil), at a dose of 0.05 $\mathrm{mL} / 100 \mathrm{~g}$ body weight per drug. Thereafter, 60 sterile polyethylene tubes $(1.3 \mathrm{~mm}$ of internal diameter and $10 \mathrm{~mm}$ long) were sealed at one end with gutta-percha (GP) (Odahcam Dentsply Indústria e Comércio Ltda., Petrópolis, RJ, Brazil) and were filled with EP1 $(n=30)$ or EP2 ( $n=30)$, using a sterile lentulo spiral (Dentsply/ Maillefer, Ballaigues, Switzerland).The tube ends sealed with GP were used as a control group.

Prior to subcutaneous implantation of the tubes, the animals had the dorsal region shaved and cleaned with $0.12 \%$ chlorhexidine gluconate (PerioGard ${ }^{\circledR}$; Pfizer Ltda, São Paulo, SP, Brazil). Two surgical incisions were done in the median region with a size 15 blade. Laterally to the incisions, the cutaneous tissue was reflected, gentle dissection was done with blunt-ended scissors and the tubes were implanted in the subcutaneous tissue. In each animal, 2 tubes containing EP 1 were placed in the scapular region and 2 tubes containing EP 2 were placed in the pelvic region. The incisions were sutured using nylon 4-0 (Ethicon Johnson \& Johnson, São Paulo, SP, Brazil).

After 7, 15, and 45 days, 5 animals of experimental each group (EP1 and EP2) were killed by anesthetic overdose. The tissues containing the tubes were removed, fixed in $10 \%$ formalin for $48 \mathrm{~h}$ and then the tubes were explanted. The tubes were examined to ensure that both AZ paste and GP were still present. The specimens were embedded in paraffin for histological processing. Longitudinal $5 \mu \mathrm{m}$-thick sections were cut at $50 \mu \mathrm{m}$ intervals, totalizing 15 sections per specimen. The sections were stained with hematoxylin and eosin and analyzed by light microscopy regarding the presence or absence of inflammation. When present, the type of inflammatory cells, intensity of the inflammatory response and its relationship with the materials were also evaluated. The occurrence of destructive processes, such as abscesses and tissue necrosis, were also considered. Tissue prolif- 
eration was also recorded when present. The biocompatibility of the experimental paste with the surrounding tissues was classified according to scores, varying with the intensity of inflammation. The following 4-point scoring system was used to determine the intensity of the inflammatory response in rat subcutaneous tissue: $1=$ absent, $2=$ mild, $3=$ moderate, and $4=$ severe. The criteria for classification of the intensities of inflammation and tissue reactions were established according to recommended standard practices for biological evaluation of dental materials (10). The scores were assigned by a blinded and experienced examiner. The histological sections were not identified and the scores were recorded on specific tables. Statistical analysis of the results was done by the Kruskal-Wallis test $(\alpha=0.05)$.

\section{RESULTS}

\section{Experimental Paste 1}

At 7 days, histological sections exhibited collagen fibers and few fibroblasts. An inflammatory process was present in most sections, being predominantly mild (score 2) and moderate to severe (scores 3 and 4) in some cases. Neutrophils were the most frequent inflammatory cells. At 15 days, there was regression of inflammation, which was absent in most sections (score 1). In some sections, few lymphocytes and macrophages (score 2) were found. Connective tissue with collagen fibers,

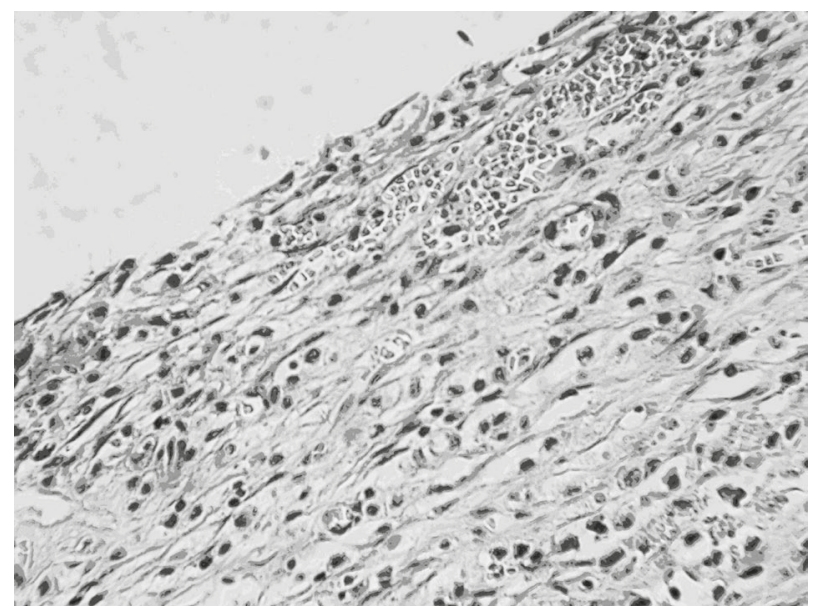

Figure 1. Experimental paste 1 (45 days). Presence of organized connective tissue with proliferation of blood vessels and absence of inflammatory process (Original magnification $\times 157.5$ ). fibroblasts and blood vessels were present at 15 days. At 45 days, a well-organized connective tissue with tissue ingrowth into the tube was observed in some cases. Inflammation was absent in all sections at 45 days (score 1) (Fig. 1), except for 2 sections, which exhibited mild inflammatory process with few lymphocytes (score 2).

\section{Experimental Paste 2}

At 7 days, the histological sections exhibited severe inflammatory process with neutrophils in all specimens and areas of abscess in most sections (scores 3 and 4). At 15 days, collagen fibers, fibroblasts and great blood vessel proliferation were seen. Inflammation was severe to moderate in most sections at 15 days (score $3)$. At 45 days, most sections exhibited inflammation of mild to moderate intensity (scores 2 and 3) (Fig. 2).

\section{Control}

The microscopic analysis of histological sections confirmed the biocompatibility of GP with the connective tissue (Fig. 3). There was absence of inflammatory process at all study periods (score 1). Only 3 sections, namely two at 7 days and one at 15 days, exhibited mild inflammatory infiltrate (score 2). At 7 days, there were poorly organized collagen fibers and fibroblasts. At 15 and 45 days, the connective tissue was well organized, with collagen fibers, fibroblasts and blood vessels.

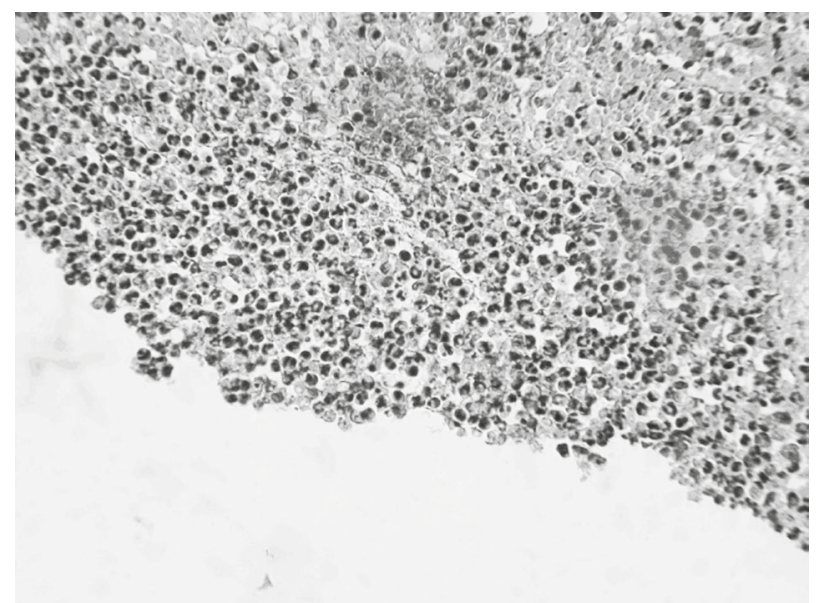

Figure 2. Experimental paste 2 (45 days). Presence of inflammatory process, large amount of neutrophils and intense proliferation of blood vessels (Original magnification $\times 157.5$ ). 


\section{Statistical Results}

The results showed no statistically significant differences between GP (control) and EP 1 ( $p>0.05)$. However, EP 2 differed significantly from GP (control) and from EP $1(\mathrm{p} \leq 0.05)$ (Table 1).

\section{DISCUSSION}

The guidelines suggested by the American Dental Association (11) and Fédération Dentaire Internationale (12) consider implantation methods as valid tests to investigate the biocompatibility of materials. Implantation of materials in the connective tissue of small animals, such as rata, is considered an adequate method to evaluate their biocompatibility. A biocompatible material should present low toxicity, with promotion of no or insignificant inflammatory response $(10,13)$. In implantation tests, the new material should be compared to a control one, which should be an acknowledged nontoxic material (14). GP is considered to have acceptable biocompatibility with no or low degree of toxicity (13), being thus used as a parameter to evaluate toxicity of the experimental pastes in the present study.

$\mathrm{AZ}$ is known as a potent inhibitor of carbonic anhydrase $(15,16)$, an enzyme present in clasts. This enzyme catalyses the reaction between carbonic acid and water, resulting in the formation of hydrogen ions $(1,17,18)$, which in turn are responsible for the decrease in $\mathrm{pH}$ in Howship

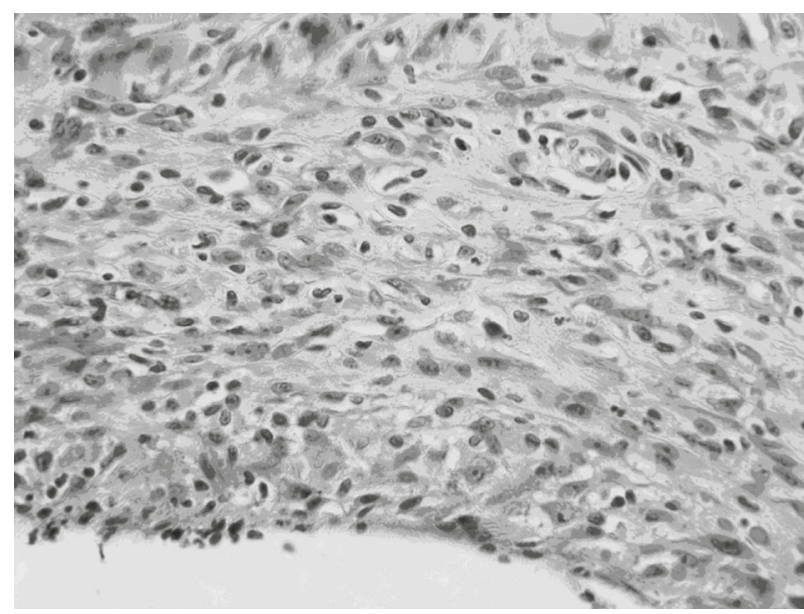

Figure 3. Control (45 days). Presence of organized connective tissue with proliferation of blood vessels and absence of inflammatory process (Original magnification $\times 157.5$ ) . lacunae $(9,17,18)$. The acidic $\mathrm{pH}$ allows release and action of other enzymes that will participate in the resorption process (18). Therefore, if carbonic anhydrase is inhibited, there will be no $\mathrm{pH}$ drop and resorption is not likely to occur.

Several studies have confirmed the efficacy of AZ in inhibiting bone resorption $(15,16)$. The idea of using $A Z$ as a substance to inhibit root resorption was presented by Mori and Garcia in 2002 (6). Briefly, an AZ solution was used for the treatment of root surfaces of rat teeth that had been intentionally avulsed and submitted to delayed replantation. The results demonstrated the occurrence of root resorption, contraindicating its use. So, the hypothesis of using AZ as an intracanal therapeutic agent was recommended. Mori et al. (2) demonstrated the efficiency of an AZ solution as an intracanal therapeutic agent in inhibiting root resorption in late reimplanted rat teeth. The development of an AZ paste would enhance its use as an intracanal medication in teeth susceptible to root resorption. This is the reason why, in this study, we investigated the biocompatibility of 2 experimental AZ pastes. The pastes used in this work had $\mathrm{AZ}$ as main component. In paste 1, saline was used as vehicle and paste 2 was prepared with propylene glycol. Saline was selected due to is biocompatibility (19), ease of handling and lack of effect on the properties of the active ingredient (15). Propylene glycol was selected because of its good consistency, viscosity, ease of handling, high quality and antimicrobial capacity (20).

According to the results of the present study, EP 1 was biocompatible with the surrounding tissues. Although an inflammatory response was observed at 7 days, the inflammation was nearly absent in the subsequent study periods. Moreover, there was no statistically significant difference between the results of this experimental paste and those of GP (control).

Table 1. Mean scores recorded for each group at each period.

\begin{tabular}{lccc}
\hline & \multicolumn{3}{c}{ Study periods } \\
\cline { 2 - 4 } Groups & 7 days & 15 days & 45 days \\
\hline Paste 1 (AZ + saline) & $2.4^{\mathrm{a}}$ & $1.3^{\mathrm{b}}$ & $1.3^{\mathrm{b}}$ \\
$\begin{array}{l}\text { Paste 2 (AZ + } \\
\text { propylene glycol) }\end{array}$ & $3.6^{\mathrm{c}}$ & $3.0^{\mathrm{c}}$ & $2.5^{\mathrm{c}}$ \\
Control (GP) & $1.3^{\mathrm{d}}$ & $1.1^{\mathrm{d}}$ & $1.0^{\mathrm{d}}$ \\
\hline
\end{tabular}

Different letters indicate statistically significant difference at $5 \%$. 
As reported by Waite et al. (15), AZ may be mixed with saline, which does not alter the properties of the active substance. Thus, EP1 may be considered satisfactory for use as an intracanal medication. Studies on teeth susceptible to root resorption should be conducted to confirm its efficacy. Unlike EP 1, EP 2 cannot be considered a biocompatible material, as inflammation was present at all study periods. Although the inflammatory response was less severe at 45 days compared to the earlier periods, it was more intense than that observed in the control group. The difference between the experimental pastes may be related to differences in vehicle used in their preparation.

In summary, EP1 (AZ + saline) was found to be biocompatible, showing similar results as those of the control material (GP), and may be considered a viable alternative for use as an intracanal medication. Further research on teeth susceptible to root resorption should also be performed to confirm its clinical application. However, EP 2 (AZ + propylene glycol) was irritating to the subcutaneous tissue of rats and thus its use should be contraindicated.

\section{RESUMO}

Este estudo investigou a biocompatibilidade de pastas experimentais a base de acetazolamida em tecido subcutâneo de rato. Duas pastas foram usadas neste estudo. Ambas continham a acetalozamida como componente principal em concentrações similares. O veículo usado na pasta experimental 1 foi o soro fisiológico e na pasta experimental 2 foi o propilenoglicol. Sessenta tubos de polietileno foram selados em uma das extremidades com guta-percha, que serviu como controle. Metade dos tubos foi preenchida com a pasta 1 e metade com a pasta 2 . Os tubos foram introduzidos no tecido subcutâneo de 15 ratos (4 tubos por animal). Aos 7, 15 e 45 dias após a cirurgia, os animais foram sacrificados e os espécimes processados em laboratório. Os cortes histológicos foram corados com hematoxilina e eosina e analisados em microscópio de luz. Escores foram estabelecidos de acordo com a intensidade do processo inflamatório: 1-sem inflamação; 2-discreta; 3-moderada; 4-severa. Os dados obtidos foram comparados estatisticamente através do teste de KruskalWallis $(\mathrm{p} \leq 0,05)$. A pasta 1 promoveu processo inflamatório aos 7 dias. Entretanto, sua intensidade diminuiu com o tempo e estava praticamente ausente aos 45 dias. Não foi observada diferença estatisticamente significante entre o controle (guta-percha) e a pasta 1. Entretanto, a pasta 2 promoveu reação inflamatória em todos os períodos experimentais, com diferença estatisticamente significante em relação ao controle. Assim, a pasta experimental de acetazolamida 1 foi considerada biocompatível como o controle deste trabalho. Já a pasta experimental 2 foi irritante aos tecidos.

\section{REFERENCES}

1. Andreasen JO, Andreasen FM. Textbook and color atlas of traumatic injuries to the teeth. 4th ed. Conpenhagen: Blackwell
Munksgaard;2007.

2. Mori GG, Garcia RB, Gomes de Moraes I. Morphometric and microscopic evaluation of the effect of solution of acetazolamide as an intracanal therapeutic agent in late reimplanted rat teeth. Dent Traumatol 2006;22:36-40.

3. Andersson L, Bodin I. Avulsed human teeth replanted within 15 minutes: a long-term clinical follow-up study. Endod Dent Traumatol 1990;6:37-42.

4. Chan AWK, Wong TKS, Cheung GSP. Lay knowledge of physical education teachers about the emergency management of dental trauma in Hong Kong. Dent Traumatol 2001;17:77-85.

5. Mori GG, Turcio KH, Borro VP, Mariusso AM. Evaluation of the knowledge on tooth avulsion of school professionals from Adamantina, São Paulo, Brazil. Dent Traumatol 2007;23:2-5.

6. Mori GG, Garcia RB. Microscopic study of the effect of root surface treatment with acetazolamida in avulsed and re-implanted rat teeth. J Appl Oral Sci (formerly Revista Fac Odont Bauru) 2002;10:180-185.

7. American Association of Endodontics. Treating the avulsed permanent tooth. www.aae.org.

8. Trope M, Moshonov J, Nissan R, Buxt P, Yesilsoy C. Short versus Long-term calcium hydroxide treatment of established inflammatory root resorption in replanted dog teeth. Endod Dent Traumatol 1995; 11:124-128.

9. Ne RF, Witherspoon DE, Gutmann JL. Tooth resorption. Quintessence Int 1999;30:9-25.

10. American National Standards/American Dental Association. Document no. 41 for recommended standard practices for biological evaluation of dental materials. New York:ANSI/ADA;1982.

11. International Organization for Standardization. ISO 7405 dentistry - preclinical evaluation of biocompatibility of medical devices used in dentistry - test methods of dental materials. Genève:ISO;1997.

12. Hauman CHJ, Love RM. Biocompatibility of dental materials used in contemporary endodontic therapy: a review. Part 2. Root-canalfilling materials. Inter Endod J 2003;36:147-160.

13. Stanford JW. Recommended standard practices for biological evaluation of dental materials. London:Fédération Dentaire Internationale; 1980.

14. Lawrence WH, Mitchell JL, Guess WL, Autian J. Toxicity of plastics used in medical practice. J Pharm Sci 1963;52:958-963.

15. Waite LC, Volkert WA, Kenny AD. Inhibition of bone resorption by acetazolamide in the rat. Endocrinology 1970;87:1129-1139.

16. Hall TJ, Higgins W, Tardif C, Chambers TJ. A comparation of the effects of inhibitors of carbonic anhydrase on osteoclastic bone resorption and purified carbonic anhydrase isozyme II. Calcif Tissue Int 1991;49:328-332.

17. Baron R, Ravesloot J, Neff L, Chakraborty M, Chatterjee D, Lomri A, et al. Celular and molecular biology of the osteoclast. In: Noda M. Celular and molecular biology of bone. San Diego:Academic Press; 1993:445-495.

18. Teitelbaum SL. Bone resorption by osteoclasts. Science 2000;289:1504-1508.

19. Simon ST, Bhat KS, Francis L. Effect of four vehicles on the $\mathrm{pH}$ of calcium hydroxide and the release of calcium ion. Oral Surg Med Oral Phatol Oral Radiol Endod, 1995;80:459-464.

20. Gomes-Filho JE, Aurélio KG, Costa MMTM, Bernabé PFE. Comparison of the biocompatibility of different root canal irrigants. $\mathrm{J}$ Appl Oral Sci 2008;16:137-144. 